\title{
An Overview of Knowledge of Traditional Medicine for Self- medication in the Community in the Era of the COVID-19 Pandemic
}

\author{
Pariyana $^{1 *}$, Muhammad Aziz ${ }^{2}$, Mariana $^{3}$, Suryadi Tjekyan ${ }^{4}$, Puji Rizki Suryani ${ }^{5}$, \\ Theodora Viani ${ }^{6}$, Salsa Amalia ${ }^{7}$ \\ ${ }^{1,2,3,4}$ Department of Public Health-Community Medicine, Faculty of Medicine, Sriwijaya \\ University, Palembang, Indonesia. \\ ${ }^{5}$ Department of Psychiatry, Faculty of Medicine, Sriwijaya University, Palembang, Indonesia. \\ ${ }^{6,7}$ Medical Doctor Profession Education, Faculty of Medicine, Universitas Sriwijaya, \\ Palembang, Indonesia. \\ * Corresponding Author: \\ Email: pariana@fk.unsri.ac.id
}

\begin{abstract}
.
Self-medication is usually used by the community to treat minor illnesses, especially during the COVID-19 pandemic, such as fever, dizziness, cough, flu, pain, ulcers, diarrhea, and others. Most self-medication leads to inappropriate drug use. Selfmedicated knowledge is the key to prevent unwanted events, one of the example is by providing education about traditional medicine for self-medication. In addition, making a plantation pharmacy is also a solution to make it easier for people to obtain traditional medicines. The method of implementing this community service activity is to provide counseling on using traditional medicine for self-medication and planting pharmacy plantation. An overview of knowledge of traditional medicine for self-medication in the community in the era of the COVID-19 pandemic is descriptive research by looking at primary data (from questionnaires) taken in a cross-sectional manner. Based on the data obtained, it can be concluded that most people have a sufficient level of knowledge (59.09\%). The community has a positive attitude towards traditional medicine self-medication as evidenced by the number of respondents who answered agree from these statements. Therefore, research can be carried out as well as counseling, education and health promotion to society with a larger sample.
\end{abstract}

Keywords: Self-medication, Traditional Medicine, Plantation Pharmacy

\section{INTRODUCTION}

According to Indonesian Ministry of Health (Depkes RI), self-medication is the most common effort by the community to deal with complaints or symptoms of illness before they decide to seek help from health service center/health worker [1,2]. Most self-medication leads to inappropriate drugs use so that cause drug interactions, drug resistance and side effects such as sensitivity reactions, allergies, shock and other side effects, as well as other losses such as inaccurate diagnosis, inappropriate use of drugs, wasting time and money [3]. The self-medicated knowledge is the key to prevent unwanted events $[3,4]$. The aim of education is to providing new knowledge for people who do not have knowledge and correcting incorrect knowledge of self- 
medication is one of the efforts to reduce unwanted incidents from recurring [5]. The recovery from self-medication give positive impacts such as reducing the risk of infection transmission during pandemic [6]. According to COVID-19 data on September $25^{\text {th }}, 2020$ in Palembang there were 2.959 confirmed cases dan 180 deaths spread across 18 sub-districts and continues to increase. Among 18 sub-districts in Palembang, Sukarame is the $3^{\text {rd }}$ highest rank of COVID-19 cases with 978 cases [7].

During this COVID-19 pandemic and the high mortality rate and the rapid transmission caused people to be unwilling to check themselves to doctors or health services, so The Activites of Planting Plantation Pharmacy and Providing Education Regarding Self-Medication of Traditional Medicines as an Effort for Disease Prevention in Adapting New Habits in COVID-19 Pandemic is expected to be useful for community especially Villa Sejahtera residents in carrying out self-medication of traditional medicine as the effort to prevent and maintain body stamina to deal with adaptating new habit during COVID-19 pandemic.

COVID-19 is an infectious disease caused by Severe Acute Respiratory Syndrome Coronavirus-2 (SARS-Cov-2), a new type of coronavirus that has never been previously identified in humans [8]. In Indonesia the first COVID-19 cases reported in March $2^{\text {nd }} 2020$ and the number continues to grow. The symptoms are usually mild and appear gradually. Some infected people do not show any symptoms and still feeling well. The most common symptoms of COVID-19 are fever, tiredness, and dry cough $[8,9]$.Self-medication is an effort that is mostly made by the communitiy in the selection and use of modern, herbal and traditional medicines to treat diseases or symptoms of their self-diagnosed diseases without consulting with a medical practitioner and medical supervision, before they decide to seek help from health service center/health workers [10-15]. Self-medication can be applied to treat minor illnesses during the COVID-19 pandemic.

Based on the result of Riset Kesehatan Dasar (Riskesdas) 2013, 35,2\% of households in Indonesia and 32,6\% in Palembang kept medicines for self-medication with $88 \%$ of them not knowing or having heard of generic drugs [12,13]. Selfmedication must be carried out in accordance with the disease, its implementation as far as possible must meet the criteria for rational drug use. The criteria of rational drug use include the accuracy of drug selection, the accuracy of drug dosage, the absence of side effects, the absence of contraindications, the absence of drug interaction, and the absence of polypharmacy [15].Medicinal plants have thousands of species. From a total about 40.000 types of medicinal plants that have been known in the world, 30.000 of them are allegedly located in Indonesia. However, only 1.200 types of plants have been used as raw materials for herbal medicines or herbs [16]. Medicinal plants generally have certain parts that are used as medicine, namely [17]:

a. Roots (radix) such as water henna and cempaka

b. Rhizomes (rhizomes) such as turmeric, ginger, and temulawak

c. Bulbs (tubers) such as shallots, garlic, and teki 
d. Flowers (flos) such as corn, pyrethria, and cloves

e. Fruits (fructus) such as pomegranate, cardamom, and Crown of the Gods

f. Seeds (cement) such as saga, areca nut, jamblang, and nutmeg

g. Wood (lignum) such as sappan, sea bidara, and sandalwood jenggi

h. Bark (cortex) such as pule, cinnamon, and pulosari

i. Trunk (cauli) such as eucalyptus, turi, and brotowali

j. Leaves (folia) such as saga, landep, miana, ketepeng, gotu kola, and sembung

k. All plants (herba) such as sambiloto, patikan kebo, and meniran

\section{METHODS}

The research was conducted at the Villa Sejahtera Housing, Sukajaya Village, Sukarame District, Palembang, with 22 respondents involved. Community service activities include counseling on traditional medicine self-medication and planting plantation pharmacies. The asssessment of community knowledge and attitudes towards traditional medicines self-medication was carried out using a questionnaire containing questions regarding definition, efficacy, logo, side effects, utilization, effectiveness, where to obtain, storage, and community attitude towards the traditional medicines utilization. Counseling, giving questionnaires, and planting traditional medicines involved the community and clinical students of IKM-IKK Department, Faculty of Medicine Sriwijaya University.

\section{RESULT AND DISCUSSION}

Community service activities include counseling regarding traditional medicines self-medication and planting plantation pharmacy. The asssessment of community knowledge and attitudes towards traditional medicines self-medication was carried out using a questionnaire. Counseling, giving questionnaires, and planting traditional medicines involved the community and clinical students of IKM-IKK Department, Faculty of Medicine Sriwijaya University as in the following picture.
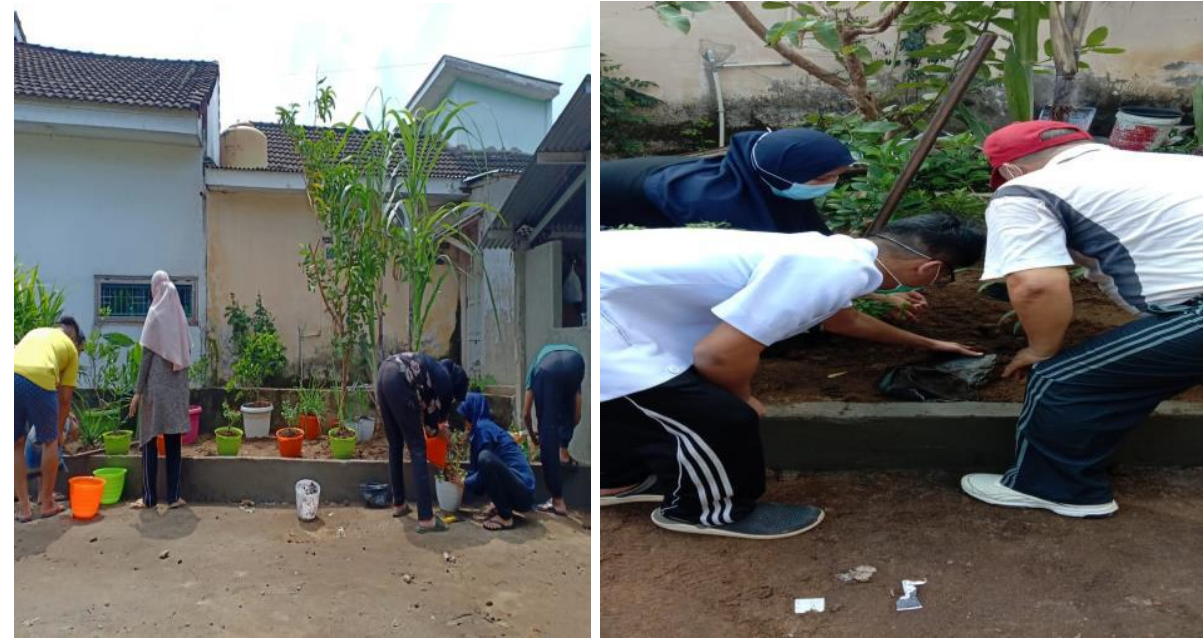

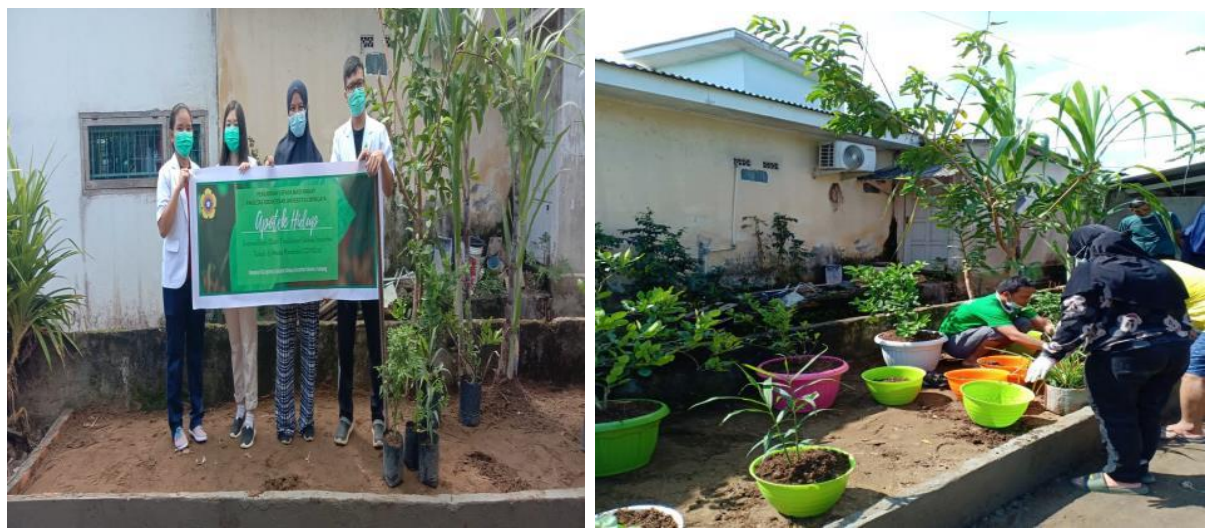

Fig 1. Planting traditional medicines

\section{Sociodemographic characteristics}

Sociodemographic characteristics that will be examined in this study include age, gender, occupation, education, and income. An overview of the distribution of respondents' sociodemographic characteristics are presented in Table 1.

Table 1. Sociodemographic characteristics of respondents

\begin{tabular}{lll}
\hline Sociodemographic characteristics & Total $(\mathbf{n}=\mathbf{2 2})$ & Percentage (\%) \\
\hline Age & 3 & \\
17 - 25 years & 8 & 13.6 \\
26-35 years & 10 & 36.4 \\
$36-45$ years & 1 & 45.5 \\
46-55 years & & 4.5 \\
Gender & 7 & \\
Male & 15 & 31.8 \\
Female & & 68.2 \\
Family members & 9 & \\
Small & 11 & 40.9 \\
Moderate & 2 & 50 \\
Big & & 9.1 \\
Last education & 4 & \\
High School/Equivalent & 18 & 18.2 \\
College & & 81.8 \\
Occupation & & \\
Civil servant & 2 & 9.1 \\
Enterpreneur & 1 & 4.5 \\
Student & 9 & 40.9 \\
Private employee & 1 & 4.5 \\
Health worker & 2 & 9.1 \\
Housewife & 1 & 4.5 \\
Unemployed & & \\
Income & 5 & 22.7 \\
Less than Rp 1000.000,00 & 2 & 9.1 \\
Rp 1000.000,00 s.d Rp 2000.000,00 & 5 & 22.7 \\
Rp 2000.000,00 s.d Rp 3000.000,00 & 6 & 18.2 \\
Rp 3000.000,00 s.d Rp 4000.000,00 & 4 & \\
More than Rp 4000.000,00 & & \\
\hline
\end{tabular}


The result of the study, it was found that in sociodemographic characteristics, the age of the most respondants was 36 to 45 years, as many as 10 people $(45,5 \%)$. This is in accordance with Supardi, et al. (2003) statement, namely the older population uses more traditional medicine than the younger population [18]. The gender of the most respondents was female, as many as 15 people $(68,2 \%)$. According to Noviana (2011), women are more likely to self-medicate with traditional medicines and are more concerned about their health, such as the use of herbal medicine for pregnancy, breastfeeding, and menstruating women [19,20].

On sociodemographic characteristics in the form of education level, most of the respondents have a high level of education, namely college as many as 18 people $(81,8 \%)$. People with higher education levels will have good knowledge about medicines. This has an impact on the rationality of drug use. People who have high knowledge tend to consider treatments that have greater benefits than side effects [21]. Respondents' occupation is dominated by private employee as many as 9 people $(40,9 \%)$. A person with job that can provide high income tends to choose a better treatment because he is able to do it.In sociodemographic characteristics of income, most of the respondents have incomes between $\mathrm{Rp} 3000.000,00$ to $\mathrm{Rp} 4000.000,00$ as many as 6 people (27,3\%). A person's economic status will affect the choice of treatment, because people tend to pay attention to the cost of treatment according to their economic capacity. According to research conducted by Supardi (2005), the reason for choosing self-medication is the illness they suffer is still mild and costeffective. This causes most people prefer to do their own treatment using traditional medicines.

\section{Self-medication knowledge}

Knowledge is the result of knowing and occurs after people have sensed a certain object [19]. Health knowledge will affect subsequent behavior, health behaviour will affect the increase in public health indicators as health education outputs [19].

Table 2. Respondents' self-medication knowledge

\begin{tabular}{|c|c|c|c|c|}
\hline \multirow[t]{2}{*}{ Self-medication knowledge } & \multicolumn{2}{|r|}{ Total } & \multicolumn{2}{|c|}{ Percentage } \\
\hline & True & False & True & False \\
\hline $\begin{array}{l}\text { 1. Traditional medicine is a mixture } \\
\text { ingredients derived from plants and } \\
\text { used for treatment }\end{array}$ & 22 & 0 & $100 \%$ & $0 \%$ \\
\hline 2. Cucumber can prevent hypertension. & 21 & 1 & $95.5 \%$ & $4.5 \%$ \\
\hline 3. Garlic can reduce blood pressure. & 22 & 0 & $100 \%$ & $0 \%$ \\
\hline 4. Turmeric can be used for tonsilitis. & 21 & 1 & $95.5 \%$ & $4.5 \%$ \\
\hline 5. This logo is a herbal medicine logo. & 4 & 18 & $18.2 \%$ & $81.8 \%$ \\
\hline $\begin{array}{l}\text { 6. This logo is Standarized Herbal } \\
\text { Medicine }(\mathrm{OHT}) \text {. }\end{array}$ & 1 & 21 & $4.5 \%$ & $95.5 \%$ \\
\hline $\begin{array}{l}\text { 7. All traditional medicines have side } \\
\text { effects. }\end{array}$ & 5 & 17 & $22.7 \%$ & $77.3 \%$ \\
\hline 8. All traditional medicines can be & 5 & 17 & $22.7 \%$ & $77.3 \%$ \\
\hline
\end{tabular}


consumed everyday.

9. Traditional medicines medication is preferred for chronic illnesses that require long treatment.

10. Traditional medicines can be taken together with modern medicines without being given time lag to increase the effectiveness of the medicine.

11. Ginger can be used to warm the body.

12. Turmeric is recommended to consumed in late pregnancy.

13. All traditional medicines can cause kidney and liver damage if used for a long time.

14. All traditional medicines have longlasting effect on the body.

15. Traditional medicine only sold in traditional drugstores.

16. The efficacy of traditional medicine is the same as the efficacy of chemical drugs.

17. Traditional medicines should be stored in closed containers.

$\begin{array}{llll}13 & 9 & 59.1 \% & 40.9 \% \\ 11 & 11 & 50 \% & 50 \%\end{array}$

$\begin{array}{llll}22 & 0 & 100 \% & 0 \% \\ 6 & 16 & 27.3 \% & 72.7 \%\end{array}$

$\begin{array}{lll}3 & 19 & 13.6 \%\end{array}$

Based on this study results, the community already has knowledge and information about definition and efficacy of traditional medicine, that the traditional medicine is preffered for chronic illnesses that require long treatment, traditional medicines that are not only sold in traditional drugstores, and to stored the traditional medicine in a closed container. Meanwhile, public knowledge about logos, side effects, use, and effectiveness of traditional medicines is still lacking.According to Supardi and Notosiswoyo (2005) study, knowledge of self-medication is generally low and public awareness to read labels on drug packaging is low, so it is understandable if not all respondents know about traditional medicine logos [18].

Generally, the use of traditional medicine is considered safer than modern medicine [22]. This is because traditional medicine has relatively fewer side effects that modern medicine. However, the side effects of traditional medicine persist. It is necessary to use traditional medicines to minimize their side effects, namely the correct drug, dose accuracy, timelines of use, how to use it, not misuse, and drugs for certain diseases [23].Like factory-made drugs, medicinal plants cannot be consumed carelessly. Medicinal plants also have dosages and rules of use that must be obeyed as well as doctor's prescriptions [22]. This does not rule out the possibility that medicinal plants have side effects [23]. WHO recommends the use of traditional medicines including herbal medicines to maintainance of health, prevention and treatment for chronic and degenerative diseases [22]. WHO also supports in improving the safety and efficacy of these herbal medicines [24]. 
The use of traditional medicine together with modern medicine needs to be given a time lag, it should not be used together at the same time [25]. Timeliness of use also needs to be considered when consuming modern medicine. The amount of turmeric (Curcuma domestica val) which is dominant in the thick turmeric tamarind ingredients needs to be considered because turmeric extract has a stimulant effect on uterine contraction and abortion [26]. Turmeric, which is believed to reduce pain during menstruation, can actually cause miscarriage if consumed during pregnancy.The content of compounds contained in traditional medicines, apart from being efficacious, may also cause side effects that can be detrimental [24]. Traditional medicines can cause kidney and liver damage if used in the long term. In Belgium, 70 people had to undergo dialysis or kidney transplant due to consuming slimming formula from the wrong plant [24].

According to the respondents, efficacy of chemical drugs (drugs given at Puskesmas/Hospital) reacts faster than Family Medicinal Plants (TOGA) [27]. Based on Nisfiyanti study (2012) the benefits of traditional medicine are felt even though the level of efficacy of these drugs takes a longer time [27]. The content of substances in medical plants and in traditional medicines is different. The right dose of traditional medicine has not been widely supported by research data. Compounding traditionally uses a pinch, a handful or a whole, which is difficult to determine with precision [24]. This affects the work effectiveness and efficacy of medicinal plants and traditional medicines.

Traditional medicines should be stored in closed container so as not to be damaged [28]. This is in accordance with Peraturan Kepala BPOM Republik Indonesia Nomor 12 tahun 2014 concerning the quality requirements of traditional medicines [28]. According to Arikunto (2006), knowledge is divided into 3 categories, good (if the subject is able to answer correctly $76-100 \%$ of all questions), sufficient (if the subject is able to answer correctly $56 \%-75 \%$ of all questions), and less (if the subject is able to answer correctly $40 \%-55 \%$ of all questions) [27]. Respondents' knowledge about traditional medicines are presented in Table 3.

Table 3. Category of respondent's self-medication knowledge

\begin{tabular}{lll}
\hline Knowledge level category & Frequency & Percentage \\
\hline Good & 0 & $0 \%$ \\
Sufficient & 13 & $59.1 \%$ \\
Less & 9 & $40.9 \%$ \\
\hline
\end{tabular}

Based on the Table 3, most of respondents have sufficient knowledge. Therefore, it is expected to increase counseling on planting plantation pharmacies and the use of traditional medicines. Thus, it is hoped that public understanding can be improved and rational traditional medicine can be achieved.

\section{Self-medication attitude}

Attitude toward health is a person's opinion or assessment of matters related to health care, such as attitudes toward communicable and non-communicable diseases, 
attitudes towards factors related to and/or influencing health, attitudes about health care facilities, and attitudes to acoid accidents. Knowledge and attitudes related to the choice of a person's treatment [29].

Table 4. Respondents' self-medication attitudes

\begin{tabular}{|c|c|c|c|c|c|c|c|c|c|c|}
\hline \multirow[t]{2}{*}{ Self-medication attitudes } & \multicolumn{2}{|c|}{$\begin{array}{l}\text { Very } \\
\text { agree }\end{array}$} & \multicolumn{2}{|c|}{ Agree } & \multicolumn{2}{|c|}{$\begin{array}{l}\text { Uncer- } \\
\text { tain }\end{array}$} & \multicolumn{2}{|c|}{ Disagree } & \multicolumn{2}{|c|}{$\begin{array}{c}\text { Very } \\
\text { disagree }\end{array}$} \\
\hline & $\mathrm{n}$ & $\%$ & $\mathrm{n}$ & $\%$ & $\mathrm{~N}$ & $\%$ & $\mathrm{~N}$ & $\%$ & $\mathrm{n}$ & $\%$ \\
\hline $\begin{array}{l}\text { 1. I also take traditional } \\
\text { medicine as a first choice } \\
\text { when sick. }\end{array}$ & 7 & 31.8 & 13 & 59.1 & 2 & 9.1 & 0 & 0 & 0 & 0 \\
\hline $\begin{array}{l}\text { 2. I also take traditional } \\
\text { medicine even though I } \\
\text { take modern medicine. }\end{array}$ & 5 & 22.7 & 13 & 59.1 & 4 & 18.2 & 0 & 0 & 0 & 0 \\
\hline $\begin{array}{l}\text { 3. In my opinion, } \\
\text { traditional medicine is } \\
\text { cheaper than moder } \\
\text { medicine. }\end{array}$ & 9 & 40.9 & 10 & 45.5 & 1 & 4.5 & 2 & 9.1 & 0 & 0 \\
\hline $\begin{array}{l}\text { 4. In my opinion, } \\
\text { traditional medicine is } \\
\text { more effective than } \\
\text { modern medicine. }\end{array}$ & 7 & 31.8 & 7 & 31.8 & 5 & 22.7 & 3 & 13.6 & 0 & 0 \\
\hline $\begin{array}{l}\text { 5. In my opinion, all } \\
\text { traditional medicine do } \\
\text { not have side effects. }\end{array}$ & 7 & 31.8 & 8 & 36.4 & 5 & 22.7 & 2 & 9.1 & 0 & 0 \\
\hline $\begin{array}{l}\text { 6. In my opinion, all } \\
\text { traditional medicines are } \\
\text { safe for consumption } \\
\text { compared to modern } \\
\text { medicine. }\end{array}$ & 7 & 31.8 & 12 & 54.5 & 1 & 4.5 & 2 & 9.1 & 0 & 0 \\
\hline $\begin{array}{l}\text { 7. Even though I feel the } \\
\text { side effects of traditional } \\
\text { medicine, I will still use } \\
\text { it again as long as the } \\
\text { side effects are not } \\
\text { harmful. }\end{array}$ & 5 & 22.7 & 11 & 50 & 3 & 13.6 & 3 & 13.6 & 0 & 0 \\
\hline $\begin{array}{l}\text { 8. I prefer to take } \\
\text { traditional medicine } \\
\text { from the herbal medicine } \\
\text { seller compared to } \\
\text { traditional medicine } \\
\text { shops/stalls. }\end{array}$ & 7 & 31.8 & 10 & 45.5 & 3 & 13.6 & 2 & 9.1 & 0 & 0 \\
\hline $\begin{array}{l}\text { 9. In my opinion, } \\
\text { traditional medicine is } \\
\text { safe to use during } \\
\text { pregnancy. }\end{array}$ & 6 & 27.3 & 12 & 54.5 & 3 & 13.6 & 1 & 4.5 & 0 & 0 \\
\hline $\begin{array}{l}\text { 10. I use traditional } \\
\text { medicine to reduce the } \\
\text { symptoms. }\end{array}$ & 4 & 18.2 & 18 & 81.8 & 0 & 0 & 0 & 0 & 0 & 0 \\
\hline
\end{tabular}

Based on the result of this study on self-medication attitudes, it can be seen that most of the respondents have a positive attitude towards traditional medicine self- 
medication as evidenced by the large number of respondents who answered agree with these statements. This positive public attitude makes it easier for people to accept the information conveyed in this activity so that it is expected to be useful for improving knowledge about rational use, side effects and information about the effectiveness of traditional medicines, as well as making it easier to obtain traditional medicines.

\section{CONCLUSION}

1. The result of this study is found that in the sociodemographic characteristics, most respondents are 35 to 45 years old. Gender of the most respondents are female. Most of the respondents have a high level of education, namely college. Occupation is dominated with private employee. Most of the respondents have income between $\mathrm{Rp} \mathrm{3000.000,00} \mathrm{to} \mathrm{Rp} \mathrm{4000.000,00}$

2. Most of the respondents have sufficient knowledge as many as 13 people (59,1\%). Meanwhile, 9 (40,9\%) people have less knowledge.

3. The community have positive attitudes towards traditional medicine selfmedication as evidenced by the large number of respondents who answered agree with these statements.

\section{ACKNOWLEDGMENTS}

The authors are grateful to the students and colleagues who have helped this community service activity. We also thank Sriwijaya University for funding this activity in the University Community Service Activity Grant 2020.

\section{REFERENCES}

[1] Suherman H and Febriana D. Patient's Knowledge Level Towards Self-medication Medicine. Viva Medika.2018.

[2] RISKESDAS. Main Results of South Sumatra Province Basic Health Research 2013. 2013 [cited 19 November 2020]. Available from: http://kesga.kemkes.go.id/images/pedoman/Data\%20Riskesdas\%202013.pdf

[3] Nining, Yeni. Education and Socialization of the Smart Community Movement Using Drugs (Gema Cermat). Indonesian Journal of Community Engagement. 2019;5(1).

[4] Jajuli M, Sinuraya R, K. Preview Article: Influencing Factors and Risks of Selfmedication Treatment. Farmaka.2018;16(1).

[5] Kalungia A C, Burger J, Godman B, Costa J de O, \& Simuwelu C. Non-prescription sale and dispensing of antibiotics in community pharmacies in Zambia. ExpertReview of Anti-Infective Therapy. 2016;14(12):1215-1223. http://doi:10.1080/14787210. 2016.1227702

[6] Simbara A, Primananda A Z, \& Tetuko A. Education of the Smart Community Movement Using Drugs (Gema Cermat) to Improve Knowledge of Self-medication.

Indonesia Jurnal Farmasi. 2020;4(1) 
[7] Dinas Kesehatan Kota Palembang. Palembang City Situation: Corona Virus Disease19. https://dinkes.palembang.go.id/tampung/dokumen/dokumen-166- 363.pdf. Diakses pada 20 November 2020.

[8] Pedoman Pencegahan Pengendalian Corona Virus Disease (COVID-19). Kementrian Kesehatan RI. 2020.

[9] World Health Organization. WHO COVID-19 Case Definition. 2020

[10] Ocan M, Obuku E A, Bwanga F dkk. Household antimicrobial self-medication: $a$ systematic review and meta-analysis of the burden, risk factors and outcomes in developing countries. BMC Public Health. 2015;15:742. https://doi.org/10.1186/s 12889-015-2109-3

[11] World Health Organization. Diaskes melalui https://www.who.int. 27 Agustus2020.

[12] Zulkarni R, Tobat S R, \& Aulia S F. Community Behavior Towards Traditional and Modern Medicines Self-medication in Sapiran Village, Aur Birugo Tiga Baleh district, Bukit Tinggi City. Jurnal Kesehatan: STIKes Prima Nusantara Bukit Tinggi. 2019;10(1): 1-5.

[13] Zulkarni R, Azyenela L, \& Penny D Y. Family Behavior in Herbal Medicine Selfmedication. Jurnal Kesehatan. 2019;10(2):84.http://doi.org/10.35730/jk.v10i2.398

[14] Suherman H dan Febriana D. Patients' Knowledge Level about Drug Selfadministration. Viva Medika.2018.

[15] Muharni S, Fina A, dan Maysharah M. Profile of Drug Information Given by Pharmacist Staff on Self Medication in Pharmacies Located at District Tampan, Pekanbaru. Jurnal Sains Farmasi \& Klinis. 2015;2(1):47-53

[16] Hamzari, (2008). Identifikasi Tanaman Obat-Obatan yang Dimanfaatkan Oleh Masyarakat Sekitar Hutan Tabo-Tabo. Jurnal Hutan dan Masyarakat. Vol. III. No 2, 111-234.

[17] Wibudi, A. The Traditional Plant,Andrographis paniculata (Sambiloto), Exibists insulin- Releasing Actions In Vitro. Acta Med Inonesia. Apr 2008. 40 (2): 63-8.

[18] Supardi, N., 2005. Self medication for Headache, Fever, Cough, and Common Cold in Ciwalen Village, Warungkondang Sub-district, Cianjur Districts, West Java. 2 (3), 134-144.

[19] Notoatmodjo, S. (2007a). Science and Art Public Health. Jakarta: Rineka Cipta.

[20] Notoatmodjo, S. (2007b). Health promotion and Behavior Science. Jakarta: Rineka Cipta

[21] Khairunnisa, N.A., Tanuwijaya, J., 2017. Patients' Knowledge Level and Selfmedication Rationality in Three Pharmacies Panyabungan City. J. Sains Farm. 3(2), 186-192.

[22] Sastroamidjojo S, 2001, Indonesian Original Medicines, Dian Rakyat, Jakarta, 170.

[23] Sumayyah S, Salsabila N. Traditional medicine: Between Efficacy and Side Effects. Majalah Farmasetika. 2017; 2(5): 1-4

[24] WHO, 2003, Traditional medicine, http://www.who.int/mediacentre/ factsheets/fs134/en/, diakses November 2020.

[25] Sari, L.O.R.K., 2012. Utilization of Traditional Medicines with Consideration of Benefits and Safety. Pharm.Sci.Res.PSR 3.

[26] Katno SP. The Level of Benefits and Safety of Medicinal Plants and Traditional Medicines. Yogyakarta: Balai Penelitian Tanaman Obat Tawangmangu Fakultas 
Farmasi Universitas Gadjah Mada; 2006 [diakses tanggal 17 November 2020]. Diunduh dari: http://www.litbang.depkes.go.id /bpom/keamanan_TO/pdf.

[27] Erlindawati M. Community Knowledge Survey on Family Medicinal Plants at Puskesmas Air Tabit. Jurnal Photon. 2015; 6(1): 115-18

[28] Peraturan Kepala BPOM Republik Indonesia Nomor 12 tahun 2014 tentang persyaratan mutu obat tradisional

[29] Supardi, N., 2005. Self medication for Headache, Fever, Cough, and Common Cold in Ciwalen Village, Warungkondang Sub-district, Cianjur Districts, West Java. 2 (3), 134-144. 